\title{
Osteodiscită cu Mycobacterium tuberculosis la 0 pacientă cu tuberculoză miliară, nefrectomie stângă şi plăgi postoperatorii suprainfectate cu germeni multirezistenți
}

\author{
Violeta Melinte ${ }^{1,2}$, Teodor Vasile ${ }^{3}$, Alexandru-Paul Burcin², Andreea Maria Pîrvan², \\ Manuela Nica ${ }^{1,2}$, Simin Florescu ${ }^{1,2}$, Corneliu Popescu ${ }^{1,2}$, Cristiana Oprea ${ }^{1,2}$ \\ ${ }^{1}$ Spitalul de Boli Infecţioase şi Tropicale „Dr. Victor Babeş“, Bucureşti, România \\ 2Universitatea de Medicină şi Farmacie „Carol Davila“, Bucureşti, România \\ ${ }^{3}$ Hôpital Bicêtre, Paris, Franţa
}

\begin{abstract}
REZUMAT
Introducere. Imunodepresia severă, apărută în contextul unor multiple intervenţii chirurgicale şi proceduri precum cateterizarea ureterală, poate favoriza reactivarea infecţiei tuberculoase şi apariţia unor forme diseminate ale acesteia (1). Pseudomonas aeruginosa este a treia cea mai frecventă bacterie gram negativă, după Escherichia coli şi Proteus mirabilis, ce determină infecţii urinare asociate îngrijirilor medicale. Morbiditatea şi mortalitatea asociate acestei etiologii rămân crescute, în pofida descoperirilor în domeniul terapiei antimicrobiene (2).

Tuberculoza miliară reprezintă o formă diseminată a bolii, fatală în lipsa unui diagnostic şi a unui tratament precoce. Această formă afectează predominant adolescenţii şi adulţii tineri, cu preponderenţă sexul feminin $(1,3)$.

Materiale şi metode. Prezentăm cazul unei paciente în vârstă de 25 de ani, care se internează în Spitalul de Boli Infecţioase şi Tropicale „Dr. Victor Babeş“ pentru osteodiscită tuberculoasă la nivel T11-T12, operată şi confirmată bacteriologic, asociată cu tuberculoză miliară, precum şi pentru sterilizarea plăgilor postchirurgicale infectate cu Pseudomonas aeruginosa multirezistent şi Staphilococcus aureus meticilino-rezistent. Rezultate. În urma administrării unei combinaţii de antibiotice cu meronem, colistin şi vancomicină şi a medicaţiei antituberculoase, pacienta a avut o evoluţie favorabilă din punct de vedere clinic, paraclinic, bacteriologic şi radiologic.

Concluzii. Efectuarea precoce a culturilor din prelevatele biologice intraoperatorii şi din secreţiile plăgilor postoperatorii, dar şi administrarea precoce a terapiei antibiotice asociate, empiric sau conform antibiogramei, atunci când există culturi pozitive, sunt esenţiale în prevenirea complicaţiilor locale şi sistemice asociate intervenţiilor chirurgicale.
\end{abstract}

Cuvinte cheie: osteodiscită tuberculoasă, tuberculoză miliară, nefrectomie, plăgi postoperatorii, suprainfecţie, Pseudomonas aeruginosa, multidrog rezistent, stafilococ auriu meticilino-rezistent (MRSA)

\section{INTRODUCERE}

Pseudomonas aeruginosa este un agent patogen care determină frecvent infecţii de tract urinar asociate cateterismelor urinare şi este deseori rezistent la tratamentul antibiotic din cauza capacităţii de a forma biofilm la suprafaţa cateterului urinar. Dezvoltarea biofilmului debutează prin apariţia unor microcolonii, care se extind şi fuzionează. Alginatul, un polizaharid anionic prezent în peretele bacterian, reprezintă unul dintre factorii de virulenţă şi este cea mai importantă componentă a biofilmului. 
Acesta este rezistent atât la antibioterapie, cât şi la mecanismele de apărare ale gazdei, fiind dificil de eradicat. Prezenţa biofilmului la nivelul dispozitivelor implantate pe tractul urinar favorizează apariţia infecţiilor urinare persistente sau recurente (4).

Pseudomonas aeruginosa este al 3-lea germene, în ordinea frecvenţei (după Escherichia coli şi Staphylococcus aureus), izolat din culturile efectuate de la nivelul plăgilor postoperatorii. Rata suprainfecţiilor plăgilor postoperatorii cu Pseudomonas aeruginosa este influenţată de factori precum vârsta, sexul şi durata spitalizării pacienţilor.

Un studiu realizat de Masaadeh H.A. şi Jaran A. a evidenţiat că infecţiile cu Pseudomonas aeruginosa localizate la nivelul plăgilor postoperatorii au o prevalenţă mai ridicată la tineri comparativ cu pacienţii vârstnici, fără a fi influenţate de sexul acestora (5). În ultimii ani, s-a observat ca incidenţa tulpinilor de $P$ aeruginosa rezistente la antibiotice este în creştere (6).

Diagnosticarea formelor de tuberculoză cu localizare extrapulmonară reprezintă o provocare, prelevatele recoltate de la pacienţi find deseori paucibacilare. Testele bacteriologice pot fi completate $\mathrm{cu}$ teste histopatologice, dar şi cu tehnici moleculare (PCR - polymerase chain reaction) care pot confirma diagnosticul (7).

Spondilodiscita tuberculoasă este întâlnită la $50 \%$ dintre pacienţii cu tuberculoză musculo-scheletală (8). Cele mai multe studii demonstrează că această formă are loc concomitent cu afectarea pulmonară (3). Localizarea la nivelul măduvei spinării a infecţiei se poate produce prin diseminare hematogenă sau pe cale limfatică, implicând ganglionii paraaortici. Frecvent, pot fi afectate simultan mai multe vertebre. Distrugerea vertebrei debutează frecvent la nivel anterior, aproape de platoul vertebral (3). Leziunile afectează discul intervertebral şi corpul vertebral inferior şi superior adiacente, coloana posterioară fiind, de regulă, respectată. În urma distrugerii acestor elemente, rezultă o deformare de tip cifotic a coloanei vertebrale (8). Diagnosticul precoce şi folosirea unei terapii antibiotice adecvate pot reduce incidenţa sechelelor osoase precum anchiloza şi diversele deformări, întâlnite frecvent la pacienţii netrataţi. Vor fi astfel reduse şi numărul intervenţiilor chirurgicale necesare pentru tratarea acestei forme de tuberculoză (9). De asemenea, un profil de rezistenţă MDR (Multiple Drug
Resistance) sau XDR (Extensive Drug Resistance) al tulpinilor de Mycobacterium tuberculosis, foarte probabil în zone endemice precum România, poate crea dificultăţi in alegerea terapiei anti-tuberculoase.

\section{PREZENTAREA CAZULUI}

O pacientă în vârstă de 25 ani, din mediul urban, se prezintă la Spitalul de Boli Infecţioase şi Tropicale „Dr. Victor Babeş“, Bucureşti, pentru iniţierea tratamentului specific pentru o osteodiscită tuberculoasă operată la nivel T11-T12 şi pentru sterilizarea plăgilor postchirurgicale infectate cu Pseudomonas aeruginosa şi Staphilococcus aureus meticilino-rezistent.

Din istoricul medical al pacientei mentionăm faptul că, cu aproximativ 2 ani anterior prezentării actuale, ea a mai fost internată în serviciul de urologie pentru infecţii recurente de tract urinar. Simptomatologia urinară a debutat în săptămâna a 20-a de sarcină. În urma investigaţiilor paraclinice, s-a diagnosticat atunci hidronefroză bilaterală şi s-a decis montarea unei sonde Cook pe ureterul dreapt şi a unei nefrostome stângi. Câteva luni mai târziu, s-a suprimat sonda Cook şi s-a păstrat nefrostoma stângă din cauza persistenţei secreţiilor purulente la acel nivel. Prima urocultură efectuată la acel moment a decelat o tulpină de Pseudomonas aeruginosa, sensibilă la piperacilină-tazobactam, ticarcilina-clavulanat şi colistin, dar rezistentă la carbapeneme, fluorochinolone şi nitrofurantoin. Ulterior, scintigrafia renală a evidenţiat absenţa completă a funcţiei renale stângi, motiv pentru care s-a decis efectuarea unei nefrectomii stângi. Radiografia pulmonară efectuată anterior intervenţiei chirurgicale nu a obiectivat modificări patologice (Fig. 1 a).

După intervenţia chirurgicală, pacienta a continuat să prezinte supuraţii recurente la nivelul plăgii postnefrostomie din care s-a izolat Pseudomonas aeruginosa sensibilă numai la Colistin, rezistentă la ureidopeniciline. Examenul IRM abdominal a confirmat prezenţa unui abces la nivelul lojei renale stângi. S-au practicat incizia şi drenajul abcesului, dar, în lipsa instituirii unui tratament antibiotic conform profilului de rezistenţă, infecţia cu Pseudomonas aeruginosa a persistat, plaga de nefrostomă supurând în continuare. Ulterior, în serviciul de urologie, s-a decis instituirea tratamentului cu Co- 
listin în monoterapie, conform antibiogramei, timp de câteva săptămâni, dar fără să se obţină o ameliorare clinică.

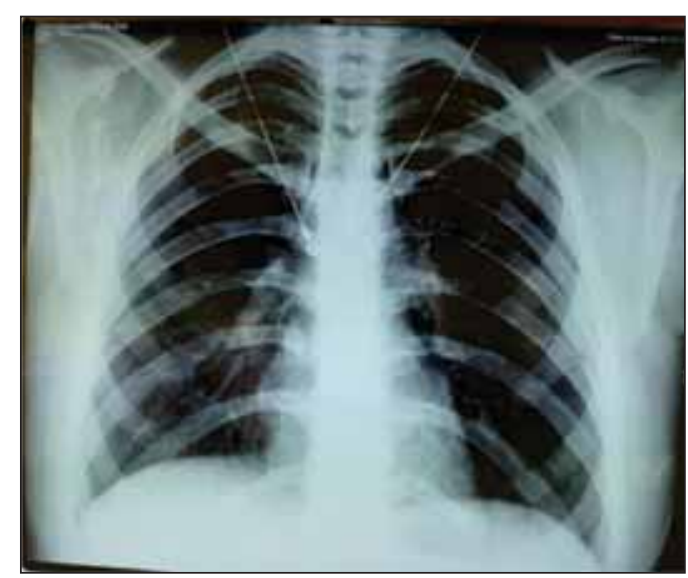

FIGURA 1 a. Radiografie toracică efectuată anterior nefrectomiei - aspect normal

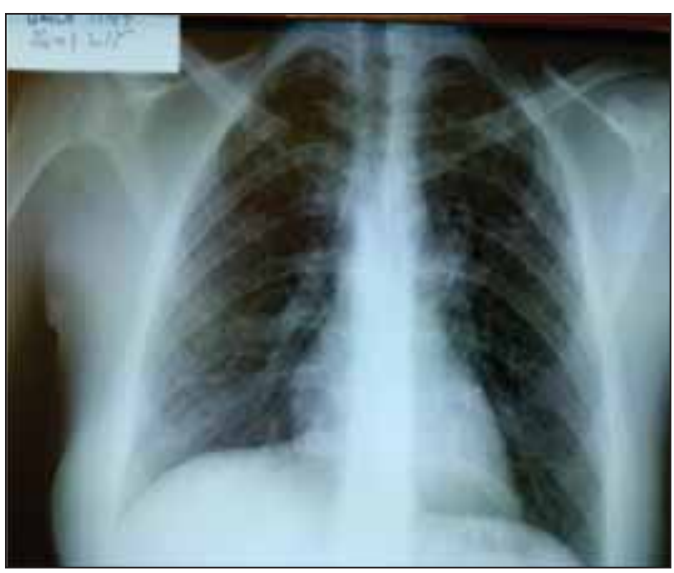

FIGURA 1 b. Radiografia toracică la internare în clinica noastră: opacități micronodulare diseminate în ambele câmpuri pulmonare

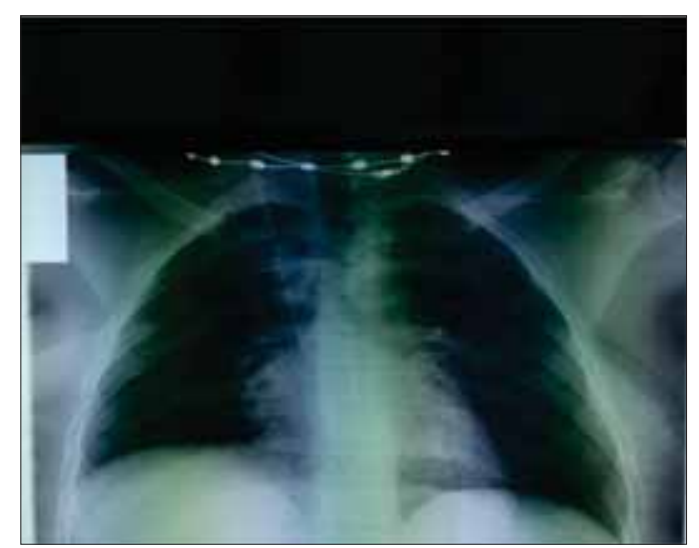

FIGURA 1 c. Radiografie toracică de controlaspect normal

$\mathrm{Cu}$ aproximativ o lună anterior prezentării în clinica noastră, pacienta a acuzat dureri dorso-lombare intense. Examenul IRM de coloană toracală a evidenţiat o leziune sugestivă pentru osteodiscită vertebrală T11-T12, atât prin zona de hiposemnal de la nivelul discului intervertebral (edem discal), cât şi hiposemnal la nivelul vertebrei T11 (Fig. 2). Pacienta a fost internată pe o secţie de neurochirurgie, unde s-a practicat osteodiscectomia. În urma examenul histopatologic, s-a suspicionat etiologia tuberculoasă a osteodiscitei, sugerat de aspectul granulomatos al piesei de osteodiscectomie. Frotiul Ziehl-Neelsen efectuat din lichidul de spălătură discală a evidenţiat prezenţa BAAR (bacili acid-alcoolo rezistenţi) şi testele de biologie moleculară au confirmat etiologia tuberculoasă a osteodiscitei (PCR - ADN MTB pozitiv) (Fig. 3).

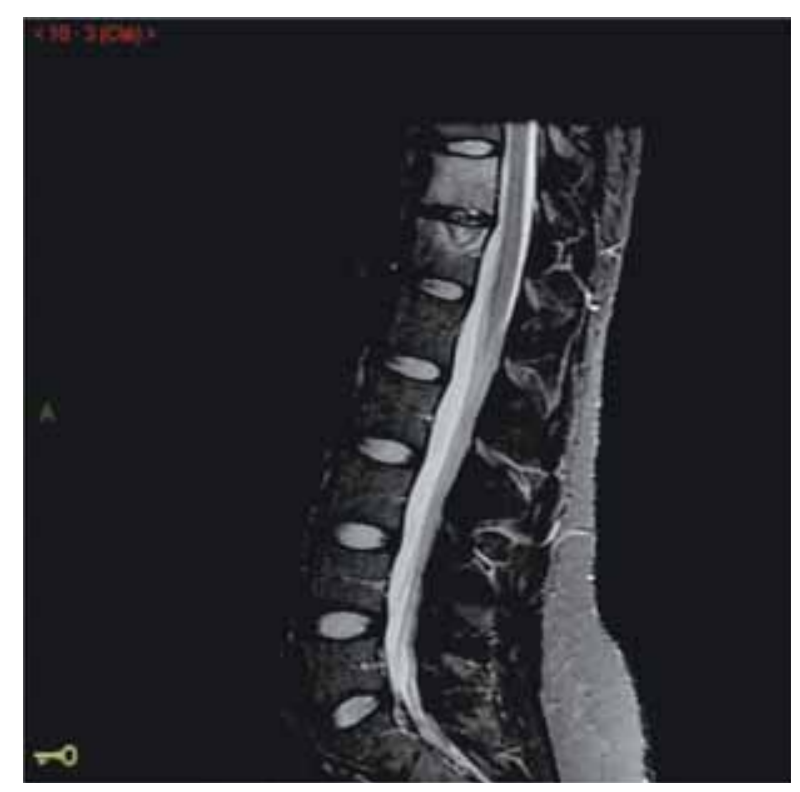

FIGURA 2. IRM (Sagital STIR) - Hiposemnal la nivel T11-T1, sugestiv pentru proces inflamator la acest nivel, $\mathrm{cu}$ acumulare de lichid şi edem perilezional

La internarea în clinica de boli infecţioase, dupa aproximativ 10 zile de la intervenţia chirurgicală, pacienta avea o stare generală mediocră, era imobilizată în aparat gipsat şi prezenta febră şi dureri la nivelul cicatricilor postoperatorii. Examenul tegumentelor a evidenţiat o plagă postoperatorie supurată (Fig. 4a), cu secreţii purulente verzui la nivelul orificiilor de sutură şi supuraţie la nivelul plăgii de nefrostomă (Fig. 4b).

Radiografia toracică a evidenţiat prezenţa unor opacităţi multiple cu caracter micronodular, diseminate în ambele câmpuri pulmonare, pledând pentru tuberculoză miliară (Fig. 1b). S-au recoltat culturi de la nivelul ambelor plăgi şi s-a iniţiat tratamentul antituberculos. Rezultatele bacteriologice au decelat atât prezenţa unei infecţii cu germeni multipli (Pseudomonas aeruginosa şi Staphylococcus aureus meticilino-rezistent) la nivelul 


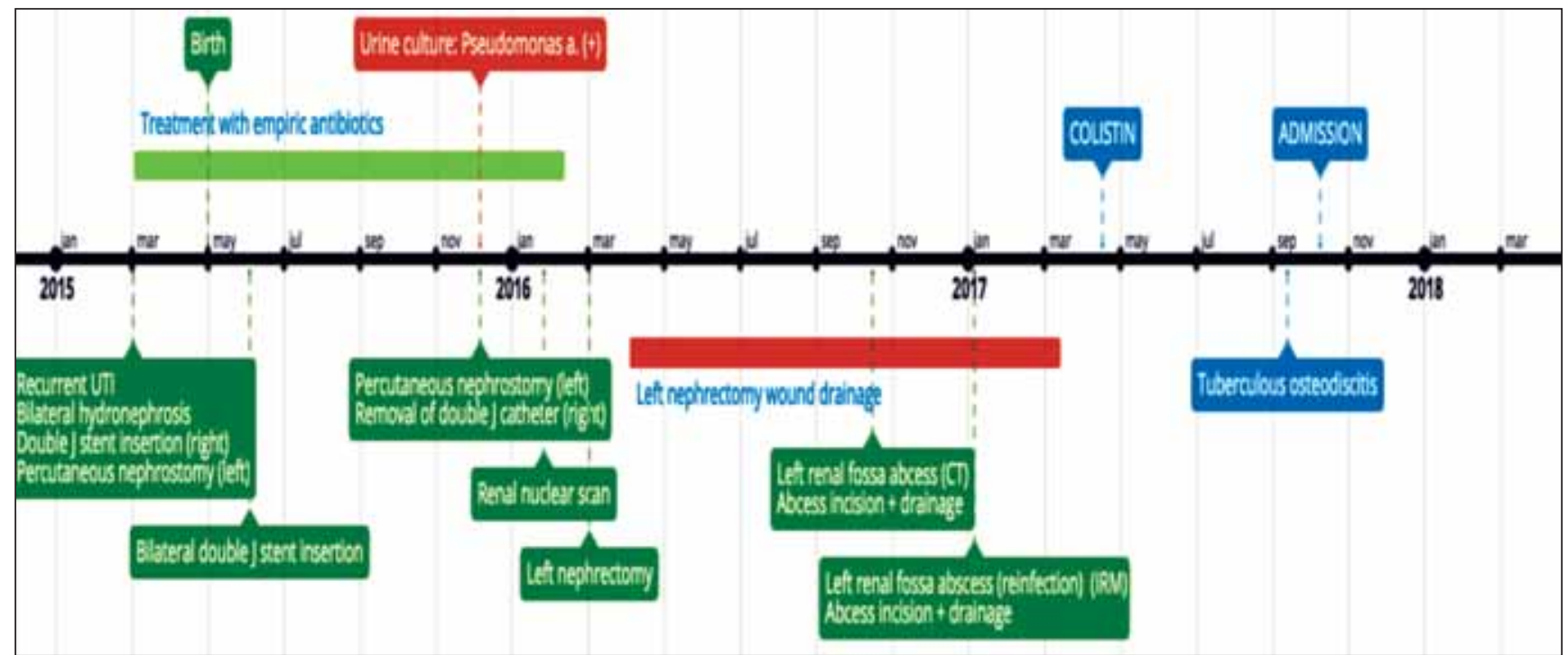

FIGURA 3. Istoric medical

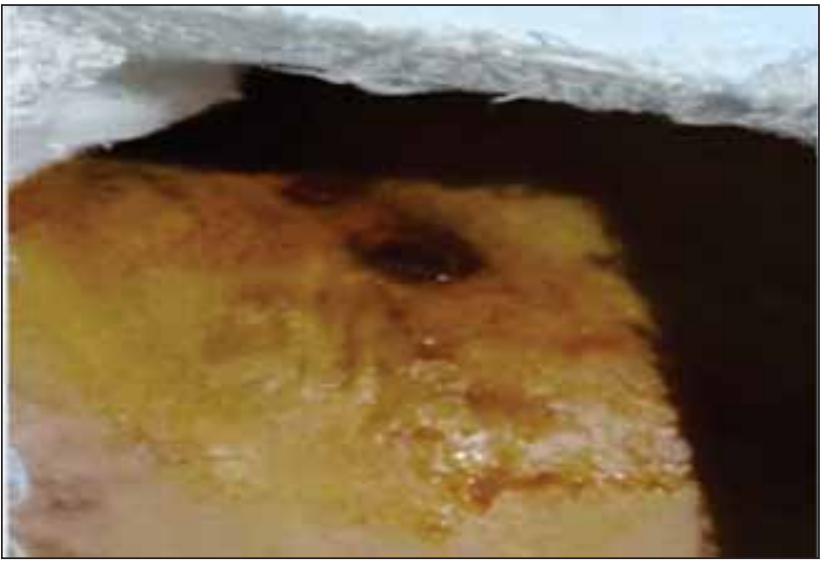

FIGURA 4 a. Plagă infectată postnefrectomie stângă la internare

plăgii de nefrostomă, cât şi suprainfecţia plăgii postosteodiscectomie cu Pseudomonas aeruginosa multirezistent, sensibil doar la Colistin.

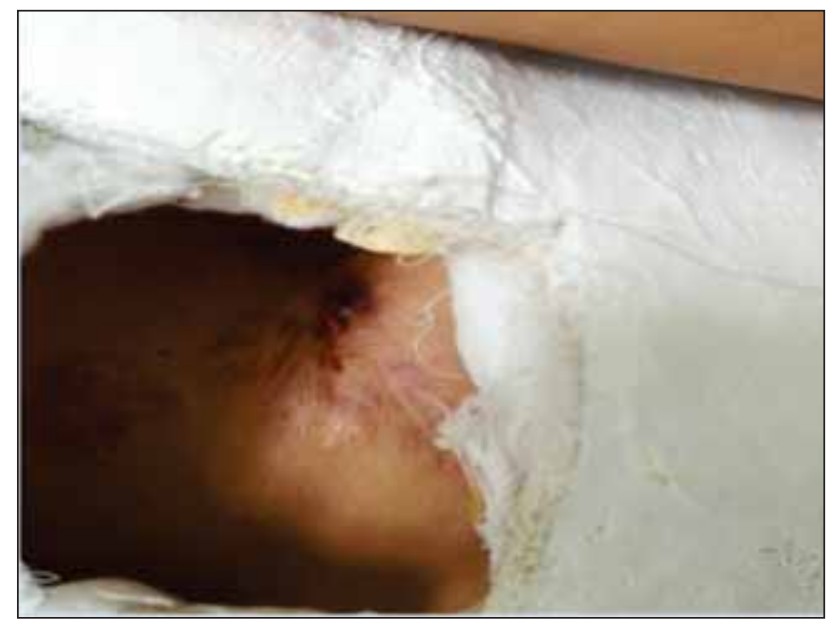

FIGURA 5 a. Cicatrice postnefrectomie stângă după 10 zile de tratament antibiotic combinat

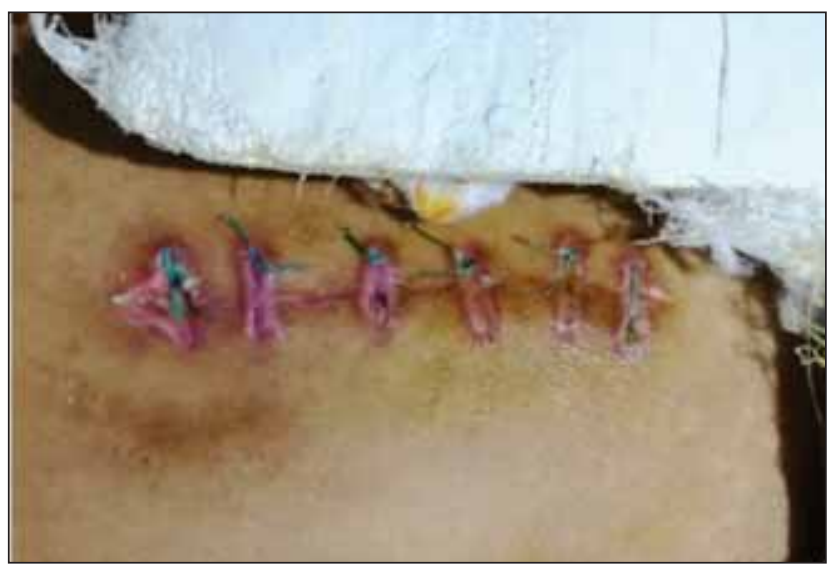

FIGURA 4 b. Cicatrice suprainfectată postdiscectomie la internare

Având în vedere etiologia deseori comună a infecţiilor de tract urinar şi a osteodiscitei, explicată

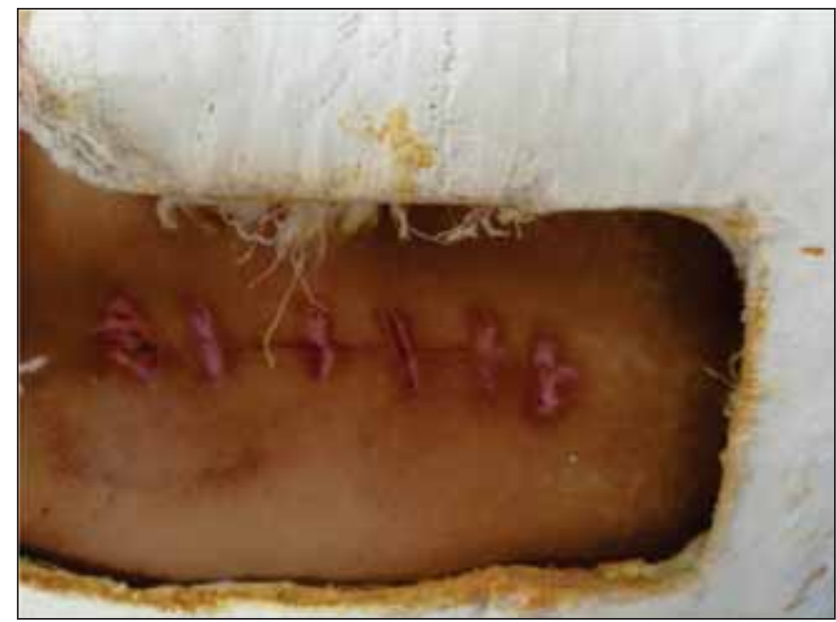

FIGURA 5 b. Cicatrice postdiscectomie după 10 zile de tratament antibiotic combinat 
de anatomia locală a trunchiurilor vasculare comune, s-a testat prezenţa $M$. tuberculosis în urină şi prin metode moleculare, dar rezultatele au fost negative.

În urma evaluării clinice şi bacteriologice, s-au stabilit următoarele diagnostice: osteodiscită tuberculoasă T11-T12; tuberculoză miliară; plăgi suprainfectate cu Pseudomonas aeruginosa (tulpină multirezistentă) şi $S$. aureus MRSA; rinichi drept unic chirurgical.

S-a iniţiat tratament antituberculos cu izoniazidă, rifampinicină, etambutol, pirazinamidă, în asociere cu tratament antibiotic cu spectru larg: Colistin, Meronem şi Vancomicină. Pe parcursul spitalizării, pacienta a prezentat o uşoară citoliză hepatică, secundară tratamentului antituberculos, şi dureri la nivelul membrelor inferioare din cauza imobilizării prelungite. $\mathrm{Cu}$ suport psihologic, kinetoterapie şi soluţii perfuzabile de reechilibrare hidroelectrolitică, evoluţia pacientei a fost lent favorabilă. După aproximativ 10 zile de tratament antibiotic, evoluţia plăgilor postosteodiscectomie şi postnefrostomie a fost favorabilă, cu dispariţia procesului de supuraţie şi cicatrizare normală (Fig. 5 a, b).

Sindromul inflamator (VSH şi proteina C-reactivă) s-a remis treptat. De asemenea, pentru eficientizarea tratamentului antimicrobian faţă de tulpina de MRSA, în vederea sterilizării plăgii de nefrostomie, s-a monitorizat şi concentraţia serică de vancomicină cu ajustarea dozelor în funcţie de aceasta (Tabelul 1).

După aproximativ o lună de tratament, s-a remarcat o ameliorare netă a aspectului radiologic pulmonar (Fig. $1 \mathrm{c}$ ).

La aproximativ 3 săptămâni după instituirea tratamentului, culturile de control au fost negative. Pacienta s-a externat, după o perioadă de spitalizare de aproximativ o lună, cu parametrii clinici, paraclinici, imagistici şi bacteriologici mult amelioraţi.

\section{DISCUTुII}

Pseudomonas aeruginosa se regăseşte printre agenţii etiologici frecvent întâlniţi ai infecţiilor urinare asociate îngrijirilor medicale. Aceasta ocupă locul al treilea ca frecvenţă după Escherichia coli şi enterococii izolaţi din uroculturi. Evoluţia bacteriuriei este direct proporţională cu durata cateterizării urinare (4). Factorii de mediu ce favorizează apariţia infecţiilor urinare cu Pseudomonas aeruginosa sunt osmolaritatea urinară, $\mathrm{pH}$-ul şi proteinele Tamm-Horsfall, dar şi variabilitatea concentraţiei ionilor de fier (2).

În cazul pacientei, infecţiile urinare recurente pe fondul unei hidronefroze agravate de sarcină, concomitent cu utilizarea de catetere urinare pe o perioadă îndelungată, au condus la pierderea funcţiei renale stângi, urmată de nefrectomie.

Antibiogramele efectuate anterior internării au relevat dobândirea progresivă a rezistenţei şi imposibilitatea sterilizării plăgii de nefrostomie sub tratament empiric. La momentul iniţierii tratamentului, culturile din plăgile postoperatorii au evidenţiat o tulpină de Pseudomonas aeruginosa multirezistentă la antibiotice cu o singură excepţie - colistinul. $\mathrm{Cu}$ toate acestea, asocierea colistin-meronem s-a administrat cu scopul obţinerii efectului sinergic. Prin mecanismul de saponificare a lipidelor membranare bacteriene, care duce la creşterea permeabilităţii acesteia, colistinul facilitează pătrunderea carbapenemelor în interiorul bacteriei. Întrun studiu de cohortă, lotul de pacienţi trataţi cu asocierea meronem şi colistin a avut o rată de supravieţuire semnificativ crescută, comparativ cu

TABELUL 1. Parametrii de laborator în evolutie

\begin{tabular}{|l|c|c|c|c|c|c|c|}
\hline Parametrii & Ziua 1 & Ziua 8 & Ziua 12 & Ziua 15 & Ziua 21 & Ziua 27 & Ziua 33 \\
\hline Leucocite $(/ \mu \mathrm{l})$ & 9.500 & 7.700 & & 3.500 & 4.300 & 3.785 & 4.000 \\
\hline Trombocite $(/ \mu \mathrm{l})$ & 508.200 & 494.000 & & 361.000 & 281.000 & 253.600 & 233.000 \\
\hline Hemoglobina $(\mathrm{g} / \mathrm{dl})$ & 10,93 & 11 & 10,5 & & & 10 & 11,36 \\
\hline ALT (U/l) & 34 & & & 171 & 133 & 49 & 28 \\
\hline Crea nina (mg/dl) & 1,2 & 1 & 1 & 1,1 & 0,9 & 0,9 & 0,9 \\
\hline VSH $(\mathrm{mm} / \mathrm{h})$ & 107 & 111 & & 66 & 48 & & 32 \\
\hline CRP $(\mathrm{mg} / \mathrm{dl})$ & 7,8 & 4,16 & & 1,36 & & 0,88 & 1,14 \\
\hline $\begin{array}{l}\text { Concentraţie reziduală de } \\
\text { vancomicină }(\mu \mathrm{g} / \mathrm{ml})\end{array}$ & & 14,8 & 15,2 & 14,7 & & 21,4 & \\
\hline
\end{tabular}


lotul de pacienţi trataţi cu colistin în monoterapie (10). De asemenea, pentru eficientizarea tratamentului cu vancomicină, s-a urmărit menţinerea unei concentraţii serice ridicate a acesteia $(15-20 \mathrm{mg} /$ dl). Astfel, la aproximativ două săptamâni de la internare, conform culturilor şi antibiogramei, s-a obţinut sterilizarea completă, atât a plăgii postosteodiscectomie, cât şi a plăgii postnefrostomie.

Având în vedere persistenţa infecţiei urinare/cutanate cu Pseudomonas sp., dovedită prin rezultate pozitive repetate ale culturilor şi localizarea anatomică a infecţiilor, a fost luată iniţial în considerare şi ipoteza unei osteodiscite cu Pseudomonas aeruginosa. Cu toate acestea, examenul radiologic efectuat înaintea intervenţiei a evidenţiat un aspect micronodular cu diseminare în ambele câmpuri pulmonare. În plus, examenul histo-patologic al piesei de osteodiscectomie a relevat un aspect granulomatos, sugestiv pentru osteodiscită tuberculoasă, confirmată ulterior prin prezenţa BAAR (bacili acido-alcoolo-rezistenţi) pe frotiu Ziehl-Neelsen şi prin metode moleculare - PCR MTB.

Tuberculoza miliară, o formă pulmonară diseminată a tuberculozei, poate fi fatală în lipsa unui diagnostic şi a unui tratament precoce. Frecvent, osteodiscita tuberculoasă este asociată cu forma pulmonară a bolii, în cazul de faţă - forma miliară. Această formă afectează predominant adolescenţii şi adulţii tineri imunodeprimaţi şi s-a observat o preponderenţă la sexul feminin $(3,1)$. Printre factorii predispozanţi ai acestei afecţiuni se numără multiple intervenţii chirurgicale şi proceduri precum cateterizarea ureterală (1). Astfel, pacienta în vârstă de 25 de ani, de sex feminin, cu o imunodepresie apărută în contextul multiplelor proceduri în sfera urologică, a dezvoltat această formă de tuberculoză, fără a prezenta tuberculoză reno-ureterală.

\section{CONCLUZII}

Cateterizarea ureterală pe o perioadă îndelungată poate avea drept urmare o scădere marcată a imunităţii. Pe fondul acestei imunodepresii, în contextul situării României în zona de endemicitate crescută a tuberculozei, se pot dezvolta forme diferite de boală, fie pulmonară, fie extrapulmonară, care, în absenţa unui tratament corespunzător, pot fi fatale.

Starea pacientei s-a ameliorat semnificativ în urma instituirii atât a tratamentului antibiotic conform culturilor şi antibiogramei, cât şi a tratamentului antituberculos. Astfel, efectuarea precoce a culturilor din prelevate biologice intraoperatorii şi din secreţiile din plagă, dar şi începerea terapiei antibacteriene combinate sunt esenţiale în scăderea morbidităţii şi prevenirea complicaţiilor locale şi sistemice. 